\title{
Journal of \\ Diabetes and Obesity

\section{Hyperinsulineamia as Risk Factor for Early Breast Cancer Recurrence Linked to Hormone Receptors and Human Epidermal Growth Factor Receptor 2}

\author{
Alkhansa Salih Mahmoud ${ }^{1,2^{*}}$, Khalid Hussein Bakheit ${ }^{3}$ \\ ${ }^{1}$ Cancer Researches Council, Sudan Academy of Science, Khartoum, Sudan \\ ${ }^{2}$ Sudan Atomic Energy Commission \\ ${ }^{3}$ Khartoum University/Faculty of medicine, Khartoum, Sudan
}

"Corresponding author: Alkhansa Salih Mahmoud, Cancer Research, Sudan Academy of Science, Khartoum, Sudan, Tel: +249915637340; E-mail: alkhansa.salih@gmail.com

\begin{abstract}
Background: Hyperinsuliunemia is a condition with excess levels of circulating insulin in the blood among non-diabetics. Hyperinsuliunemia may increase breast cancer developing probability.

Purpose: to investigate the role of hyperinsuliunemia in early recurrence in breast cancer by estrogen receptor (ER), progesterone receptor (PR) and human epidermal growth factor receptor 2 (HER2).

Methods: 50 patients with invasive breast cancer in stage II and III in age range 17 - 65 years, involved in this study and classified into five subtypes of ER, PR and HER2, and followed prospectively for 2 years from beginning treatment based on insulin serum levels.

Results: In newly diagnosed patients the mean concentrations and standard deviation were $(17.11 \pm 10.17)$, while the insulin levels in the patients after chemotherapy treatment were $(26.06 \pm 15.69)$, when the tow means were compared by $t$. test the blood concentration of insulin was high significantly in patients as control ( $p>0.001$ ). Regarding hormone receptors and HER2, the insulin levels in ERPR-HER2 - and ER- PR-HER2 + increased significantly after chemotherapy ( $\mathrm{p}=$ 0.005 and 0.047 ) respectively. 10 of triple negative breast cancer patients suffered recurrence.

Conclusion: Hyperinsuliunemia and weight change after chemotherapy may consider as risk factors for breast cancer recurrence among patients with triple-negative breast cancer.
\end{abstract}

Received date: January 27, 2017

Accepted date: August 31, 2017

Published date: September 12, 2017

Citation: Salih Mahmoud, A., et al. Hyperinsulineamia as Risk Factor for Early Breast Cancer Recurrence Linked to Hormone Receptors and Human Epidermal Growth Factor Receptor 2. (2017) J Dent Oral Care 4(3): 1- 4.

DOI: $10.15436 / 2376-0494.17 .1323$

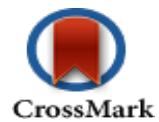

Keywords: Breast cancer; Recurrence; Hyperinsuliunemia; Hormone receptors

\section{Introduction}

Breast cancer is the most common cancer in women worldwide and $70 \%$ of breast cancer deaths occur in women from low-income and middle-income countries ${ }^{[1]}$. It has been estimated that more than one million new cases occur worldwide annually ${ }^{[2]}$. It is a major cause of morbidity and mortality in the world, although many risk and prognostic factors of breast cancer have been established, and understanding of breast cancer prognosis is still poorly understood ${ }^{[3]}$. Breast cancer is a heterogeneous disease characterized by varying responses to therapeutic agents and significant differences in long-term survival $^{[4]}$. Abnormal blood levels of anabolic hormones are associated with increased cancer developing probability. Several epidemiological studies have suggested that high insulin levels may play major role in breast cancer development ${ }^{[5]}$. High circulating insulin levels have also been associated with a risk of breast cancer recurrence $^{[6]}$. The relationship between insulin and breast 
cancer has been assessed by several epidemiological studies. Hyperinsuliunemia was reported to be a significant factor for incident breast cancer ${ }^{[7]}$, elevated insulin has been correlated with poor outcomes in breast cancer patients ${ }^{[8]}$. Estrogen receptor and progesterone receptor determinations are established procedures in the routine management of patients with breast cancer and are considered both prognostic and predictive factors; they are considered primarily as a predictive factor for response to therapy and adjuvant hormonal therapy including aromatase inhibitors as letrozole and tamoxifen ${ }^{[9]}$. Human epidermal receptor 2 (Her2), also known as ErbB2 or Neu in rodents) belongs to the epidermal growth factor receptor family of receptor tyrosine kinases (RTK), the Her2 oncogene is expressed in approximately $25 \%$ of human breast cancers and is associated with metastatic progression and poor outcome ${ }^{[10]}$. Breast cancer recurrence can occur at any time, but most recurrences happen in the first 5 years after treatment ${ }^{[11]}$. The aim of this study was to a achieve role of higher insulin levels in early recurrence correlated to hormone receptor status HER2 in patients with breast cancer during the first two years following treatment.

\section{Methods}

\section{Population}

Fifty non-diabetic women with newly diagnosed breast cancer were randomly selected at a mean of age 4lyears (range 17 - 65 years). Patient's information included type of breast cancer, weight and hormone receptor status. Results of hormone receptors were obtained from the histopathology laboratory done as routine test for breast cancer patients at radiation and isotopes center- Khartoum. This study was approved by the ethical committee in the ministry of health.

\section{Follow-up}

For fifty patients' insulin levels were measured before and after chemotherapy, they were followed prospectively for 24 months from the beginning of treatment.

\section{Sample collection}

$5 \mathrm{ml}$ of venous blood sample was collected from each patient in a plain vacationer tube, and then centrifuged at 3000 r.p.m for 10 minutes to obtain the serum; the serum was kept in a serum container and stored at $-20^{\circ} \mathrm{C}$ in a deep freezer until analyzed.

\section{Techniques}

Radioimmunoassay used for insulin measurement and immunohistochemistry used for the assay hormone receptor and HER2 status.

\section{Statistical analysis}

The data were analyzed using SPSS, version 16.0; Statistics included paired T-Test and correlation coefficient. The results were considered significant when P-Value $<0.05$

\section{Results}

The findings of the study regarding insulin levels, in the newly diagnosed patients were $(17.11 \pm 10.178 \mathrm{mIU} / \mathrm{L})$, while the insulin levels in the mean concentrations and standard devia- tion of insulin level in the patients post chemotherapy treatment were $(26.06 \pm 15.698 \mathrm{mIU} / \mathrm{L})$ as shown in figure 1 , when the tow means were compared by t. test the blood concentration of insulin was high significantly in patients as control $(\mathrm{p}>0.001)$. Patients were classified into five subtypes groups explain in table 2 . Furthermore, the triple negative breast cancer (ER-PR-, Her2-) and subtype ER-PR-, Her2+ have significant association with high insulin serum levels after chemotherapy compared to other breast cancer subtypes. A strong positive correlation found between BMI pre and post chemotherapy $(\mathrm{r}=0$. 929, $\mathrm{P}=<$ 0.001 ) as explained in figure 2 . Insulin serum levels increased in $22(44 \%)$ patients before chemotherapy and increased in 35 $(70 \%)$ patients after chemotherapy.

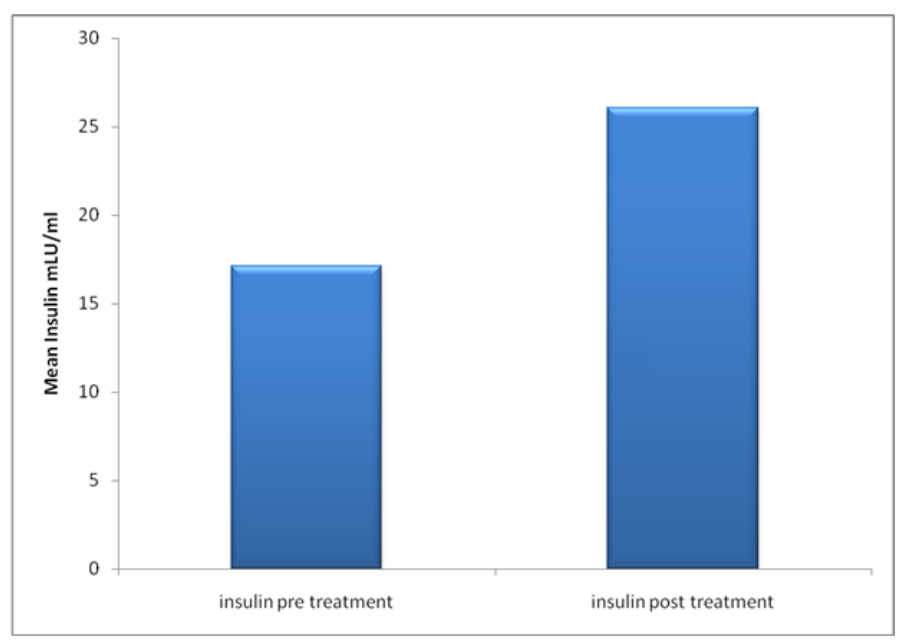

Figure 1: Comparison of insulin levels between patients pre and post chemotherapy.

Table 1: Insulin mean and STD among ER/PR and HER2 in breast cancer.

\begin{tabular}{|l|l|l|l|}
\hline Hormone receptors and HER2 & \multicolumn{2}{|l|}{ Insulin levels (mIU/L) } \\
\hline Subtypes & $\begin{array}{l}\text { Breast cancer pa- } \\
\text { tients }\end{array}$ & Mean STD & p-value \\
\hline ER- PR-HER2- & $\begin{array}{l}\text { Pre chemotherapy } \\
\text { Post chemotherapy } \\
\text { (n= 22) }\end{array}$ & $\begin{array}{l}15.9 \pm 8.3 \\
26.7 \pm 19.4\end{array}$ & 0.005 \\
\hline ER+ PR+HER2+ & $\begin{array}{l}\text { Pre chemotherapy } \\
\text { Post chemotherapy } \\
\text { (n=12) }\end{array}$ & $19.0 \pm 15.6$ & 0.3 \\
\hline ER+ PR-HER2+ & $\begin{array}{l}\text { Pre chemotherapy } \\
\text { Post chemotherapy } \\
\text { (n=5) }\end{array}$ & $17.0 \pm 8.3$ & 0.5 \\
\hline ER+ PR+HER2- & $\begin{array}{l}\text { Pre chemotherapy } \\
\text { Post chemotherapy } \\
\text { (n= 5) }\end{array}$ & $20.2 \pm 8.0$ & 0.2 \\
\hline ER- PR- HER2+ & $\begin{array}{l}\text { Pre chemotherapy } \\
\text { Post chemotherapy } \\
\text { (n=6) }\end{array}$ & $15.6 \pm 8.9$ & 0.047 \\
\hline
\end{tabular}

Note: $\mathrm{ER}=$ Estrogen receptor, $\mathrm{PR}=$ Progesterone receptor, HER2 = Human epidermal growth factor receptor $2,+=$ positive, $-=$ negative, $\mathrm{n}=$ number of patients. 


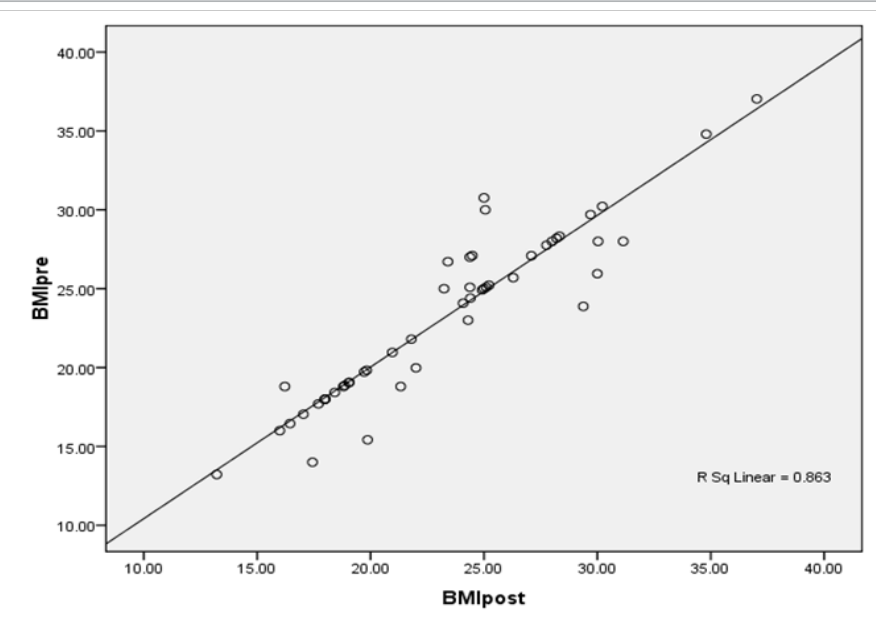

Figure 2: Correlation of BMI pre and post chemotherapy in Breast cancer patients.

\section{Discussion}

The present study focused specifically on serum insulin concentration among breast cancer subtypes. The findings are in agreement with a study which showed that in women who are not known diabetics, and followed prospectively, fasting insulin levels correlated with recurrence and death after breast cancer treatment ${ }^{[12]}$, also the results of this study confirmed that elevated insulin levels in the circulation have been reported to be associated with an adverse prognosis during the first 5 years after diagnosis ${ }^{[13]}$. This finding supports other studies which have shown that triple-negative breast cancers have more aggressive clinical course than other forms of breast cancer ${ }^{[14]}$; there is a high prevalence of triple negative tumors among younger women and poorer survival ${ }^{[15]}$. Several studies reported that insulin resistance is associated with increased incidence of breast cancer with all subtypes ${ }^{[16]}$. Plasma insulin level is a predictor of postmenopausal breast cancer in ER negative patients ${ }^{[17]}$. Several studies have shown that metabolic syndrome may be an important prognostic factor for breast cancer ${ }^{[18]}$. However, one study described the effects of metformin on the hormonal/metabolic profile and tumor cell proliferation estimated by ki-67 labeling index in non-diabetic breast cancer patients, and show that there is considerable heterogeneity in these $\mathrm{e}^{[19]}$. These findings are relevant to design breast cancer prevention and treatment trials with metformin in women with insulin resistance or HER2-positive tumors $^{[20]}$. Early survival following breast cancer is reduced in women with diabetes-related hyperinsuliunemia ${ }^{[21]}$, also another study reported that diabetic patients with breast cancer had adverse characteristics such as negative status of hormone receptors. The association could not be attributed to family history of breast cancer, and was independent of obesity, indicating that diabetes may have an independent effect on cancer prognosis ${ }^{[22]}$. Obesity is an independent prognostic factor for developing metastases and for death as a result of breast cancer; the effects of adjuvant therapy seem to be lost more rapidly in patients with breast cancer and obesity. The authors also suggested that adjuvant chemotherapy and endocrine therapy were less effective over time periods greater than 10 years for patients with BMI $>30$ although it was unclear whether this effect was mediated by poor responsiveness to treatment or differences in biology ${ }^{[23]}$. Weight variation has been reported as a side effect of chemother- apy treatment in breast cancer patients and has been identified as a factor of poor prognosis. Causes of weight variation during chemotherapy and mechanisms involved in the poor prognosis have been little studied; another study showed that insulin resistance may be a common mechanism to explain the weight change during chemotherapy ${ }^{[24]}$. The findings of this study suggest that hyperinsuliunemia is preferred to insulin resistance which occurs in non diabetics due to metabolic abnormalities has been related to breast cancer prognosis.

\section{Conclusion}

Hyperinsuliunemia associated with weight change after chemotherapy and may be consider as risk factors for breast cancer recurrence among triple-negative breast cancer. Further studies should be recommended to increase insulin sensitivity and improving breast cancer therapy. 


\section{References}

1. Lee, B.L., Liedke, P.E., Barrios, C.H., et al. Breast cancer in Brazil: present status and future goals. (2012) Lancet Oncol 13(3): e95-e102. PubMed | CrossRef|Others

2. Parkin, D.M., Fernandez, L.M. Use of statistics to assess the global burden of breast cancer. (2006) Breast J 12(1): S70-S80.

PubMed | CrossRef| Others

3. Qiu-Li, Z., Wang-Hong, X., Meng-Hua, T. Biomarkers of the Metabolic Syndrome and Breast Cancer Prognosis. (2010) Cancers (Basel) 2(2): 721-739.

PubMed | CrossRef | Others

4. Guenther, S., Muirhead, L.J., Speller, A.V., et al. Spatially resolved metabolic phenotyping of breast cancer by desorption electrospray ionization mass spectrometry. (2015) Cancer Res 75(9): 1828-1837.

PubMed | CrossRef | Others

5. Pisani, P. Hyper-insulinaemia and cancer, meta-analyses of epidemiological studies. (2008) Arch Physiol Biochem 114(1): 63-70.

PubMed | CrossRef | Others

6. Formica, V., Tesauro, M., Cardillo, C., et al. Insulinemia and the risk of breast cancer and its relapse. (2012) Diabetes Obes Metab 14(12): 1073-1080.

PubMed | CrossRef | Others

7. Gunter, M.J., Hoover, D.R., Yu, H., et al. Insulin, insulin-like growth factor-I, and risk of breast cancer in postmenopausal women. (2009) J Natl Cancer Inst 101(1): 48-60.

PubMed | CrossRef | Others

8. Erickson, K., Patterson, R.E., Flatt, S.W., et al. Clinically defined type 2 diabetes mellitus and prognosis in early-stage breast cancer. (2011) J Clin Oncol 29(1): 54-60.

PubMed | CrossRef | Others

9. Fisher, B., Jeong, J.H., Bryant, J., et al. National Surgical Adjuvant Breast and Bowel Project randomised clinical trials. Treatment of lymph-node-negative, oestrogen-receptor-positive breast cancer: longterm findings from National Surgical Adjuvant Breast and Bowel Project randomised clinical trials. (2004) Lancet 364(9437): 858-868.

PubMed |CrossRef | Others

10. Ferguson, R.D., Gallagher, E.J., Cohen, D., et al. Hyperinsulinemia Promotes Metastasis to the Lung in a Mouse Model of Her2-mediated Breast Cancer. (2013) Endocr Relat Cancer 20(3): 391-401.

PubMed | CrossRef|Others

11. Jatoi, I., Tsimelzon, A., Weiss, H., et al. Hazard rates of recurrence following diagnosis of primary breast cancer. (2005) Breast Cancer Res Treat 89(2): 173-178.

PubMed |CrossRef |Others

12. Goodwin, P.J., Ennis, M., Pritchard, K.I., et al. Fasting insulin and outcome in early-stage breast cancer: results of a prospective cohort study. (2002) J Clin Oncol 20(1): 42-51.

PubMed | CrossRef $\mid$ Others
13. Goodwin, P.J., Ennis, M., Pritchard, K.I., et al. Insulin- and obesity-related variables in early-stage breast cancer: correlations and time course of prognostic associations. (2012) J Clin Oncol 30(2): 164-171. PubMed |CrossRef|Others

14. Dent, R., Trudeau, M., Pritchard, K.I., et al. Triple-negative breast cancer: clinical features and patterns of recurrence. (2007) Clin Cancer Res 13(15 Pt 1): 4429-4434.

PubMed |CrossRef|Others

15. Bauer, K.R., Brown, M., Cress, R.D., et al. Descriptive analysis of estrogen receptor (ER)-negative, progesterone receptor (PR)-negative, and HER2-negative invasive breast cancer, the so-called triple-negative phenotype: a population-based study from the California Cancer Registry. (2007) Cancer 109(9): 1721-1728.

PubMed |CrossRef|Others

16. Davis, A.A., Kaklamani, V.G. Metabolic Syndrome and Triple-Negative Breast Cancer: A New Paradigm. (2012) Int J Breast Cancer 2012(2012): 809291.

PubMed | CrossRef| Others

17. Hirose, K., Toyama, T., Iwata, H., et al. Insulin, insulin-like growth factor-I and breast cancer risk in Japanese women. (2003) Asian Pac J Cancer Prev 4(3): 239-246.

PubMed |CrossRef| Others

18. Pasanisi, P., Berrino, F., De Petris, M., et al. Metabolic syndrome as a prognostic factor for breast cancer recurrences. (2006) Int J Cancer 119(1): 236-238.

PubMed | CrossRef | Others

19. DeCensi, A., Puntoni, M., Gandini, S., et al. Differential effects of metformin on breast cancer proliferation according to markers of insulin resistance and tumor subtype in a randomized presurgical trial. (2014) Breast Cancer Res Treat 148(1): 81-90.

PubMed | CrossRef | Others

20. Goodwin, P.J., Pritchard, K.I., Ennis, M., et al. Insulin-lowering effects of metformin in women with early breast cancer. (2008) Clin Breast Cancer 8(6): 501-505.

PubMed | CrossRef| Others

21. Lipscombe, L.L., Goodwin, P.J., Zinman, B., et al. The impact of diabetes on survival following breast cancer. (2008) Breast Cancer Res Treat 109(2): 389-395.

PubMed | CrossRef | Others

22. Wolf, I., Sadetzki, S., Gluck, I., et al. Association between diabetes mellitus and adverse characteristics of breast cancer at presentation. (2006) Eur J Cancer 42(8): 1077-1082.

PubMed | CrossRef | Others

23. Ewertz, M., Jensen, M.B., Gunnarsdóttir, K.Á., et al. Effect of obesity on prognosis after early-stage breast cancer. (2011) J Clin Oncol 29(1): 25-31.

PubMed | CrossRef | Others

24. Thivat, E., Thérondel, S., Lapirot, O., et al. Weight change during chemotherapy changes the prognosis in non metastatic breast cancer for the worse. (2010) BMC Cancer 10: 648 PubMed | CrossRef| Others
Ommega Online Publishers

Journal Title: Journal of Diabetes and Obesity (JDO)

Journal Short Name: J diabetes Obes
Journal ISSN: 2356-0494

E-mail: diabetes@ommegaonline.com

Website: www.ommegaonline.org 